Original Article

\title{
Comparison study between the treatment of Hepatitis $C$ virus with (peg-interferon, ribavirin, silymarin) and (peg-interferon, ribavirin) in Baghdad teaching hospital.
}

\author{
Khalid A. Al-Khazraji* \\ MBChB , MD, CAMB , FRCP , FACP
}

Abstract:

Background: Infection with Hepatitis $\mathrm{C}$ virus $(\mathrm{HCV})$ is a major cause of chronic liver disease, WHO estimated that about 170 million people are infected with Hepatitic $\mathrm{C}$ virus, Silymarin (Legalon) have been recently shown to be effective in treatment of Hepatitic $\mathrm{C}$ virus infection.

Objectives: The effectiveness of Legalon (Silymarin) on viral load in patients with Hepatitic C virus infection.

JFac Med Baghdad 2017; Vol.59 No .1

Receive June. 2016

Accepted Nov .2016
Patients and methods: A prospective case - control study included 400 patients with Hepatitis $\mathrm{C}$ virus infection. 200 patients (group A) were treated with (peg-interferon, ribavirin, silymarin) the other 200 patients (group B) were treated with (peg-interferon, ribavirin) . only G1 \& G4 genotypes were included , viral load were assessed initially and after 3 months in patients with positive viral load.

Results: Viral load follow in group A, Hepatitis C Viral load was reported in 150 cases giving a response rate of $75 \%$ while in the 200 cases of group B the response was reported in 110 giving an overall response rate $55 \%$, this indicate that cases in group A had a significant higher response rate than those in group B.

Conclusion: Patients taking Silymarin $(420 \mathrm{mg} /$ day $)$ for 3 months showed a decrease in viral load, effectiveness of silymarin was more in Genotype 1 than in the Genotype 4, the response was better in low viral load patients ( less than $600000 \mathrm{IU} / \mathrm{ml}$ ).

Keywords: Hepatitis C, Treatment, Silymarin effects on treatment.

\section{Introduction:}

Infection with hepatitis $\mathrm{C}$ virus (HCV), is a major cause of chronic liver disease, WHO estimated that about 170 millions people (3\% of the world's population) are infected with HCV and $3-4$ millions persons are newly infected each year. (1-3) Prevalence rates vary widely, ranging from $0.15 \%$ in Scandinavia to about $15 \%$ in Egypt. (4). the overall prevalence in United States is $1.8 \%$, corresponding to an estimated 3.9 million persons with HCV infection. (5). about $80 \%$ of newly infected patients progress to develop chronic infection and Cirrhosis develops in about $10-20 \%$ of persons with chronic infection. Liver cancer develops in $1-5 \%$ of persons with chronic infection over a period of $20-30$ years. $(5,6)$. Diagnostic tests for hepatitis $\mathrm{C}$ virus (HCV) can be either:

1- Serologic assays that detect antibodies to Hepatitis C.

2- Molecular assays that detect or quantify HCV RNA. $(7,8,9$,

Treatment of HCV RNA or Viral Load, Viral load is an important determinant of treatment response. The lower the HCV RNA (viral load) the better the chance of eradicating the hepatitis $\mathrm{C}$ virus. Low viral load under: $800000 \mathrm{IU} / \mathrm{mL}$, High viral load: over800 $000 \mathrm{IU} / \mathrm{mL}$. some recent studies have suggested that the cut-off between low and high viral load may be too high. These studies have shown that people with viral load under $400000-600000 \mathrm{IU} / \mathrm{mL}$ respond

*Dept. Of medicine, university of Baghdad.

Drkhalidg.t1959@yahoo.com better to current medications compared to those who have a viral load above $400000-600000 \mathrm{IU} / \mathrm{mL}$. (10) The goal of antiviral therapy in patients with chronic $\mathrm{HCV}$ is to eradicate HCV RNA, which is predicted by attainment of a sustained virologic response (SVR). An SVR is associated with a 98 to $100 \%$ chance of being HCV RNA negative during long term follow - up $(11,12)$. And attaining an SVR has been associated with decreases in all-cause mortality, liver related death, need for liver transplantation, hepatocellular carcinoma rates, and liver related complications $(12,13)$. Patients with genotype 1 should be treated with Peginterferon, ribavirin, and a protease inhibitor. Patients with other genotypes are treated with Peginterferon and ribavirin; all have new modalities for interferon free drugs. 14 Peginterferon alfa-2a and Peginterferon alfa-2b differ in their pharmacokinetics. Studies comparing the two Peginterferons in combination with ribavirin have had variable results $(10,13,15)$. While the largest randomized trail (IDEAL) showed that Peginterferon alfa-2a and Peginterferon alfa - $2 b$ appeared to have comparable efficacies in the treatment of chronic hepatitis C (16). in 2010 meta-analysis suggests a slight advantage for Peginterferon alfa-2a (17). For patients receiving Peginterferon alfa- $2 \mathrm{a}$, the ribavirin dose is $1000 \mathrm{mg}$ for patients who weight $<=75 \mathrm{~kg}$ or $1200 \mathrm{mg}$ for those weight $>75 \mathrm{~kg}$. For patents receiving Peginterferon alfa$2 \mathrm{~b}$, the ribavirin dose is $800 \mathrm{mg}$ for patients who weight $<65$ $\mathrm{kg}$ or $1000 \mathrm{mg}$ for those weights $65-85 \mathrm{~kg}, 1200 \mathrm{mg}$ for $>85$ to $105 \mathrm{~kg}, 1400 \mathrm{mg}$ for $>105 \mathrm{~kg}$. 18 Side effects are observed 
in almost $80 \%$ of patents receiving Peginterferon and ribavirin combination therapy for chronic HCV. $(19,20)$ include: Flu-like symptoms, anemia, neutropenia, thrombocytopenia, rashes, hair loss, thyroid dysfunction, depression, fatigue, irritability and mania, non-productive cough, dyspnea, ophthalmologic disorders such as retinal hemorrhage, teratogenicity, and exacerbations of autoimmune diseases. 21, 22 Legaon-SIL (LS) is a form of SBN (silybummarianum) which is water - soluble formulation of the dihydro-succinate sodium salt of SBN A and SBN B in equal proportion. Recent results from a pilot study in patients with chronic HVC using LS indicate that some Flavonolignans may have antiviral activity $(24,25)$ Silibinin is assumed to be partly reabsorbed after being deconjugated again and enters into an entero-hepatic circulation. Legalon given for three months duration with pegylated interferon and ribavirin $(23,24)$ Milk thistle seed work might protect liver cells from toxic chemicals and drugs. It also seems to have antioxidant and anti-inflammatory effects. Milk thistle plant extract might enhance the effect of estrogen and some research suggests that milk thistle may limit liver damage after exposure to industrial poisons such as toluene and xylene.

Aim of the Study: To study the effects of Legalon treatment in addition to Peginterferon \& ribavirin on viral load in hepatitis $\mathrm{C}$ virus as compared to those receiving only Peginterferon \& ribavirin at the end of 12 weeks treatment in the medical city of Baghdad teaching hospital.

\section{Patients and Methods}

In a prospective case control study all 400 patients with hepatitis $\mathrm{c}$ virus infections fulfilled the criteria of treatment, patients were randomized given either peg.interferon, ribavirin and legalon (silymarin) or peg.interferon and ribavirin. 200 patients were given a triple therapy for 12 weeks group (A). Age, sex and weight of the patients were recorded. The other 200 patients received peg.interferon and ribavirin group (B) with age, sex and weight of the patients were recorded The study was conducted in the Medical City Baghdad teaching Hospital, from July 2012 to November 2013. Quantitative Viral load assessed initially and then after 12 weeks for all studied group with testing liver biochemistry and complete blood picture . Viral load considered high if it's $>600,000$ $\mathrm{iu} / \mathrm{ml}$ and viral load consider low when it's $<600,000 \mathrm{iu} / \mathrm{ml}$ [34] . Patients only with Gl \& G 4 included in this study. We excluded the pregnancy, decompensated liver failure, HBV, renal failure, we considered time patient response' when. $>=$ $2 \log$ decrease or undetectable at end of 12 weeks from initial viral load (partial or early virological response).

Statistical analysis: The statistical analysis and data management were performed by using the statistical package for social sciences (SPSS) version 20, IBM, US, 2010. Descriptive statistics were presented as mean and standard deviation (SD) for the mean age, and frequencies and proportions for other variables. The response rate was calculated as the number of cases with viral load $<2 \log$ or undetected levels divided by the total number of cases in the group. Student's t test was used to compare the mean age of cases in between the two studied group. Chi square test (X2) was used to compare between the studied groups regarding the categorical variables, including the sex, the change in hematological parameters and the total response according to the genotypes

\section{Results}

There were 400 cases enrolled in this study, represent the two studied groups, group A treated with Pegylated interferon and Ribavirin with Legalon and group B (without Legalon), each group consisted of 200 cases.

Age Distribution: Was in group A $(41.3 \pm 10.3)$ years with a range of $19-73$ years, and it was $(42.5 \pm 9.1)$ years with a range of $21-63$ years in group $B$, the difference in age was statistically insignificant, $\mathrm{P}>0.05$, table 1 .

Sex distribution: In group A males and females were about equally distributed, 98 males (49\%) and 102 (51\%) females, with a female to male ratio of 1.04:1. In group B, males were $110(55 \%)$ and females were $90(45 \%)$ with a female to male ratio of 1.22:1.

The mean weight of the patients in group A was $77.8 \pm 14.4$ $\mathrm{kg} \backslash \mathrm{m} 2$ and $76.3 \pm 13.6 \mathrm{~kg} \backslash \mathrm{m} 2$ in group B with no statistically significant difference in between both groups $(\mathrm{P}=0.45)$.

Table 1. Age, sex and weight distribution of the studied group.

\begin{tabular}{rcccc}
\hline Variable & & Group A & Group B & P.value \\
\hline \multirow{3}{*}{ Age } & Mean & $41.3 \pm 10.3$ & $42.5 \pm 9.1$ & \multirow{2}{*}{$0.14(\mathrm{MS})$} \\
\cline { 2 - 4 } & Range & $19-73$ & $21-63$ & \\
\hline \multirow{3}{*}{ Sex } & Male n (\%) & $98(49 \%)$ & $110(55 \%)$ & \multirow{2}{*}{$1.0(\mathrm{NS})$} \\
\cline { 2 - 4 } & Female n (\%>) & $102(51 \%)$ & $90(45 \%)$ & \\
\cline { 2 - 4 } & Female/male ratio & $1.04: 1$ & $1.22: 1$ & \\
\hline \multirow{2}{*}{ Weight } & Mean \pm SD & $77.8 \pm 14.4$ & $76.3 \pm 13.6$ & \multirow{2}{*}{$0.45(\mathrm{NS})$} \\
\cline { 2 - 4 } & Range & $44-109$ & $41-102$ & \\
\hline
\end{tabular}

NS; not significant, SD; standard deviation

Distribution of genotypes and viral load of studied group: The distribution of genotypes and viral load in both studied groups is shown in table 2; out of the 200 cases in group A , $114(57 \%)$ had genotype 1, and 86 (43\%) had genotype 4, compared to $110(55 \%)$ and $90(45 \%)$ in group (B), respectively. Regarding the viral load, 72 cases of group A $(36 \%)$ and $56(28 \%)$ of group B had viral load $<600000$, the remaining 128 cases (64\%) in group A and 144 cases (72\%) in group B, had viral load of $>600000$ No statistically significant differences had been found between the studied groups neither in genotypes nor in viral load, in both comparison P.value $>$ 0.05 . 
Table 2. Distribution of cases in studied groups according to genotype and viral load.

\begin{tabular}{ccccccccc}
\hline Variable & & \multicolumn{2}{c}{ Group A } & \multicolumn{2}{c}{ Group B } & \multicolumn{2}{c}{ Total } & P-value \\
\hline & & No & $\%$ & No & $\%$ & No & $\%$ & \\
\hline Genotype & 1 & 114 & 57.0 & 110 & 55.0 & 224 & 56.0 & 0.78 \\
\hline & 4 & 86 & 43.0 & 90 & 45.0 & 176 & 44.0 & NS \\
\hline Viral load & $<600000$ & 72 & 36.0 & 56 & 28.0 & 128 & 32.0 & 0.23 \\
\hline & $>600000$ & 128 & 64.0 & 144 & 72.0 & 272 & 68.0 & NS
\end{tabular}

Distribution of response to treatment according to the viral load and Genotypes in group $A$ :

In group A there were 114 cases had genotype 1, 25 of them had viral load of $<600000$ and 64 had viral load $>600000$. Response was reported in $44(88 \%)$ cases of those 50 cases with viral load $<600000$ and in $46(71.9 \%)$ cases of those 64 with viral load $>600000$. The comparison of response according to this sub-categorization revealed that group A cases with genotype 1 and viral load $<600000$ had significantly higher response rate than their cohort with viral load $>600000$, $(\mathrm{P}=0.031)$, Table 2 . In the remaining 86 cases in the same group A who had genotype 4 viral load of $<600000$ was found in 22 and viral load of $>600000$ was found in 38 , it had been significantly found that cases with genotype 4 and had viral load of $<600000$ had the higher response rate than those with viral load of $>600000$, Table 2 . These findings revealed undoubtly that cases of group A with viral load of $<600000$ (No. $=72$; (50 with genotype 1 and 22 with genotype 4 ) had the higher response rate than those with viral load of $>600000$ (No. = 128, (64 had genotype 1 and 64 had genotype 4) in both genotypes $1 \& 4$. And the total response in both genotypes according to viral load was reported in $66(91.6 \%)$ of the 72 with viral load $<600000$ compared to $84(65.6 \%)$ of those 128 cases with viral load of $>600000(\mathrm{P}=0 . .001)$.

Table 3. Distribution of response according to viral load in cases with genotype $1 \& 4$ of group $A$

\begin{tabular}{|c|c|c|c|c|c|}
\hline \multicolumn{6}{|c|}{ Group A (genotype 1) } \\
\hline \multirow{2}{*}{ Viral load } & \multicolumn{2}{|c|}{ Response } & \multicolumn{2}{|c|}{ No response } & \multirow{2}{*}{ Total } \\
\hline & No & $\%$ & No & $\%$ & \\
\hline$<600000$ & 44 & 88.0 & 6 & 12.0 & 50 \\
\hline$>600000$ & 46 & 71.9 & 18 & 28.1 & 64 \\
\hline Total & 90 & 78.9 & 24 & 21.1 & 114 \\
\hline \multicolumn{6}{|c|}{ P.Value $=0.031$ sig } \\
\hline \multicolumn{6}{|c|}{ Group A (genotype 4) } \\
\hline \multirow{2}{*}{ Viral load } & \multicolumn{2}{|c|}{ Response } & \multicolumn{2}{|c|}{ No response } & \multirow{2}{*}{ Total } \\
\hline & No & $\%$ & No & $\%$ & \\
\hline$<600000$ & 22 & 100.0 & $\mathbf{0}$ & 0.0 & 22 \\
\hline$>600000$ & 38 & 59.4 & 26 & 40.6 & 64 \\
\hline Total & 60 & 69.8 & 26 & 30.2 & 86 \\
\hline
\end{tabular}

Distribution of response to treatment according to the viral load and genotypes in group $B$.
In group B it had been also found that cases with genotype 1 and viral load of $<600000$ had significantly $(\mathrm{P}=0.022)$ higher response rate than those with viral load $>600000$ of the same genotype group, (Table 2). On the other hand in those cases with genotype 4 , the response rate was higher in those with viral load $<600$ than those with viral load $>600000$ and the differences was statistically significant $(p=0.003)$, Table 2 . Furthermore the overall response rate of cases with viral load $<600$ was higher than those with viral load $>600000$.

Table 4 Distribution of response according to viral load in cases of group B

with genotype $1 \& 4$.

\begin{tabular}{|c|c|c|c|c|c|}
\hline \multirow{2}{*}{ Viral response } & \multicolumn{2}{|c|}{ Response } & \multicolumn{2}{|c|}{ No response } & \multirow{2}{*}{ Total } \\
\hline & No & $\%$ & No & $\%$ & \\
\hline$<600$ & 24 & \multirow{2}{*}{$\begin{array}{c}70.6 \\
47.4\end{array}$} & 10 & 29.4 & \multirow{2}{*}{$\begin{array}{l}34 \\
76\end{array}$} \\
\hline$>600$ & 36 & & 40 & 52.6 & \\
\hline Total & 60 & 54.5 & 50 & 45.9 & 110 \\
\hline \multicolumn{6}{|c|}{ P.Value $=0.04$ sig } \\
\hline \multirow{2}{*}{ Viral response } & \multicolumn{2}{|c|}{ Response } & \multicolumn{2}{|c|}{ No response } & \multirow{2}{*}{ Total } \\
\hline & No & $\%$ & No & $\%$ & \\
\hline$<600$ & 18 & 81.8 & 4 & 18.2 & 22 \\
\hline$>600$ & 32 & 47.1 & 32 & 52.9 & 64 \\
\hline Total & 50 & 55.6 & 36 & 44.4 & 86 \\
\hline \multicolumn{6}{|c|}{ P.Value $=0.01$ sig } \\
\hline
\end{tabular}

Comparison of response to treatment between genotypes 1 and 4 cases in group $A \& B$.

As it shown in table 4 it had been significantly found that cases in group A with genotype 1 had higher response rate than those with genotype 4 of the same group, the response rate was $78.9 \%$ in those 114 cases with genotype 1 compared to $69.8 \%$ in those 86 cases with genotype 4 , however, the difference was statistically insignificant, $(\mathrm{P}=0.138)$. Similar to that reported in group A, there was no statistically significant difference in response rate when compare the genotype 1 vs. genotype 4 in group B, out of the 110 cases with genotype 1 the response was reported in 60 cases $(54.5 \%)$ compared to $55.6 \%$ of those 90 cases with genotype 4 , table 5 .

Table5.Comparison of response to treatment between genotypes1 and 4 cases in group $\mathbf{A} \& \mathbf{B}$.

\begin{tabular}{|c|c|c|c|c|c|}
\hline & \multicolumn{2}{|c|}{ Response } & \multicolumn{2}{|c|}{ No response } & \multirow{2}{*}{$\begin{array}{c}\text { Total } \\
\text { No. }\end{array}$} \\
\hline & No & $\%$ & No & $\%$ & \\
\hline Genotype 1 & 90 & 78.9 & 24 & 21.1 & 114 \\
\hline Genotype 4 & 60 & 69.8 & 26 & 30.2 & 86 \\
\hline Total & 150 & 75.0 & 50 & 25.0 & 200 \\
\hline \multicolumn{6}{|c|}{ P.Value $=0.35 \mathrm{~ns}$} \\
\hline & \multicolumn{2}{|c|}{ Response } & \multicolumn{2}{|c|}{ No response } & \multirow{2}{*}{ Total } \\
\hline & No & $\%$ & No & $\%$ & \\
\hline Genotype 1 & 60 & 54.4 & 50 & 45.5 & 110 \\
\hline Genotype 4 & 50 & 55.6 & 40 & 44.4 & 90 \\
\hline Total & 110 & 55.0 & 90 & 45.0 & 200 \\
\hline
\end{tabular}

Comparison of response to treatment of cases with genotypes 1 of group A vs. group B. 
The comparison of response rate of the cases with genotype 1 vs. those in group B with the same genotype, revealed that cases with genotype 1 in group A had higher response rate than those in group B, $78.9 \%$ vs. $54.5 \%$ respectively, $(\mathrm{P}=0.006)$, Table 6.

Table 6. Comparison of response of cases with genotype 1 in both studied groups.

\begin{tabular}{|c|c|c|c|c|c|}
\hline & \multicolumn{2}{|c|}{ Response } & \multicolumn{2}{|c|}{ No response } & \multirow{2}{*}{ Total } \\
\hline & No & $\%$ & No & $\%$ & \\
\hline $\begin{array}{c}\text { Genotype } 1 \\
\text { Group A }\end{array}$ & 90 & 78.9 & 24 & 21.1 & 114 \\
\hline $\begin{array}{c}\text { Genotype } 1 \\
\text { Group B }\end{array}$ & 60 & 54.5 & 50 & 45.5 & 110 \\
\hline Total & 150 & 67.0 & 74 & 33.0 & 224 \\
\hline
\end{tabular}

Comparison of response to treatment of cases with genotypes 4 of group

A vs. group B

Table 7 shows the response rate of cases with genotype 4 in both studied group, the response rate was $69.8 \%$ genotype 4 cases of group A which was higher than the $55.6 \%$ of cases in group B with genotype 4, however the difference in response rate didn't reach the statistical significance $(\mathrm{P}>0.05)$.

Table 7.

\begin{tabular}{cccccc}
\hline & \multicolumn{2}{c}{ Response } & \multicolumn{2}{c}{ No response } & \multirow{2}{*}{ Total } \\
\cline { 2 - 5 } & No & $\%$ & No & $\%$ & \\
\hline $\begin{array}{c}\text { Genotype 4 } \\
\text { Group A }\end{array}$ & 60 & 69.8 & 26 & 30.2 & 86 \\
\hline $\begin{array}{c}\text { Genotype 4 } \\
\text { Group B }\end{array}$ & 50 & 55.6 & 40 & 44.4 & 90 \\
\hline Total & 110 & 62.5 & 66 & 37.5 & 176 \\
\hline \multicolumn{5}{c}{ P.Value $=0.17$ NS } \\
\hline
\end{tabular}

Comparison of total response to treatment in between the studied group.

In the 200 cases of group A the response was reported in 150 cases giving a response rate of $75 \%$ while in the 200 cases in group B the response was reported in 110 giving an overall response rate of $55 \%$, this indicated that cases in group $\mathrm{A}$ had significant higher response rate than those in group B, $(\mathrm{P}=0.001)$, Table 3 .

Table8. The overall response rate of cases of both studied groups.

\begin{tabular}{ccccccc}
\hline \multirow{2}{*}{ Response } & \multicolumn{2}{c}{ Group A } & \multicolumn{2}{c}{ Group B } & \multicolumn{2}{c}{ Total } \\
\cline { 2 - 7 } & No & $\%$ & No & $\%$ & No & $\%$ \\
\hline Response & 150 & 75.0 & 110 & 55.0 & 260 & 65.0 \\
\hline No response & 50 & 25.0 & 90 & 45.0 & 140 & 35.0 \\
\hline Total & 200 & 100.0 & 200. & 100.0 & 400 & 100.0 \\
\hline \multicolumn{6}{c}{ P.Value $=0.003$ signifigant } \\
\hline \multicolumn{7}{c}{}
\end{tabular}

\section{Discussion}

Silymarin has been claimed to have a beneficial effect on various types of liver injury, including alcoholic liver disease, drug and toxin induced hepatotoxicity, and acute and chronic viral hepatitis. Our results showed that using silymarin significantly decreased viral load regarding the Gl as when comparing Group A with Group B. Jessica Wagoner et al determined that silymarin (legalon) had antiviral effects against hepatitis $\mathrm{C}$ virus cell culture and infection that included inhibition of virus entry, RNA and protein expression, and infectious virus production; this study support our result regarding HCV RNA. Tanamly et al in a doubleblinded trial; One hundred and seventy-seven consenting residents of an Egyptian village with chronic hepatitis $\mathrm{C}$ virus were randomly assigned to receive the silymarin and other multivitamins treatment. Evaluated silymarin (legalon) had no significantly improvement HCV-RNA[21] but symptoms being much improve so which suggest longer time treatment. in our results were not agreed with our findings. The difference might be because of that they don't use ribavirin, peg. interferon and Genotypes of patients. Treatment with Legalon (silymarin) down regulates HCV Gl, which means decrease HCVRNA titer after treatment with silymarin this study which support our study Hamid Kalantaria et al indicated that in 55 patients with chronic hepatitis $\mathrm{C}$ performing silymarin $(650 \mathrm{mg} /$ day) for 6 months, improving serum HCV- RNA titer, serum aminotransferases (ALT, AST), hepatic fibrosis and patient's quality of life. This study support our study for the effectiveness on the viral load. Peterferenci. et al find in 16 patients received $10 \mathrm{mg} / \mathrm{kg} /$ day silymarin (LegalonSil; Madaus, Koln, Germany) for 7 days. In a subsequent dose-finding study, 20 patients received $5,10,15$, or $20 \mathrm{mg} / \mathrm{kg} /$ day SIL for 14 days. In both protocols, PegIFN-2a/RBV were started on day 8. Viral load was determined daily, HCV-RNA, at week 12, was significantly decreased. This study support our result by decreased HCV viral load titer by silymarin. Other studies done In Shepherd, J. et al this study supported our result of the lowest response in Gl (without legalon) as compared to G4 (without legalon), there was more response in genotype 4 but, statistically insignificant regarding the group B. In Wirth $\mathrm{S}$. et al $[70$ two studies stratified the results in genotype 1 patients according to the viral load before treatment. In the first study, the cut-off level was $600.000 \mathrm{U} / \mathrm{L}: 32 \%$ of patients with genotype 1 and high viral load $(>600: 000 \mathrm{U} / \mathrm{L})$ and $73 \%$ with low viral load $(<600,000 \mathrm{U} / \mathrm{L})$ achieved SVR. The differences in response according to viral load in both group (A) response to treatment was more in viral load $<600000$ $\mathrm{IU} / \mathrm{ml}$ as compared with viral load $>600000 \mathrm{IU} / \mathrm{ml}$. Response was statistically significant in group (A) and more with (viral load $<600000 \mathrm{iu} / \mathrm{ml}$ ) and less in the (viral load $>600000 \mathrm{iu} / \mathrm{ml})$ ; the differences was statistically significant. Our results were also supported by FuadHasan MD et al[71]This support is for our study regarding G4 viral load as we found an increase in response regarding the low viral load .

In our study we found increased response in $\mathrm{G} 4 \mathrm{HCV}$ in the 
group ( A) as compared with G4 of HCV of group (B), but the results were not significant statistically; However, we didn't have any similar work to compare it with our results.

\section{Conclusion:}

Our study indicated that patients with $\mathrm{HCV}$ received silymarin (420 mg/day) for 3 months improved serum HCV-RNA titer, the effectiveness of silymarin was more in Gl than in the G4. 3. The response was more in low viral load $<600,000 \mathrm{IU} / \mathrm{L}$ and was more in genotype 4 in group A than in group B.

\section{References:-}

1. World Health Organizatiom Hepatitis C. Factsheet No 164 (updated Oct 2000). (accessed 3 Feb 2008).

2. Patel K, Muir AJ, McHutchisonJG:Diagnosis and treatment of chronic hepatitis C infection.BMJ2006,332(7548):1013-7.

3. US CDC Recommendations for prevention and control of hepatitis $C$ virus (HCV) infection and HCV-related chronic disease: Center for Disease Control and Prevention. MMWR 1998, 47:l-39.

4. Sievert $W$, Altraif I, Razavi HA, Abdo A, Ahmed EA, AlomairA,et al: A systematic review of hepatitis $C$ virus epidemiology in Asia, Australia and Egypt Liver Int2011,31(2):61-80.

5. WHO Hepatitis C: Global prevalence.WklyEpidemiol Rec 1997,72:341-344.

6. Houghton M, Weiner A, Han J, Kuo G, Choo QL, et al. Molecular biology of the hepatitis $C$ viruses: implications for diagnosis, development and control of viral disease. Hepatology 1991; 14:381

7. Alter HJ. New kit on the block: evaluation of secondgeneration assays for detection of antibody to the hepatitis $C$ virus. Hepatology 1992; 15:350

8. Smith BD, Drobeniuc J, Jewett A, Bernard M. Branson, Richard S. Garfein, et al. Evaluation of three rapid screening assays for detection of antibodies to hepatitis $C$ virus. J Infect Dis 2011; 204:825.

9. Vermehren J, Kau A, Gartner BC, Göbel R, Zeuzem $S$, Sarrazin C.. Differences between two realtime PCRbased hepatitis $C$ virus $(\mathrm{HCV}$ ) assays (RealTime $\mathrm{HCV}$ and CobasAmpliPrep/CobasTaqMan) and one signal amplification assay (Versant HCV RNA 3.0) for RNA detection and quantification. J ClinMicrobiol 2008; 46:3880.

10. Alan Franciscus. Predictors of Treatment Response HCSP fact sheet $・$ Version 9 January 2014

11.Morgan TR, Ghany MG, Kim HY, Snow KK, Shiffman $M L$, De Santo JL. Outcome of sustained virological responders with histologically advanced chronic hepatitis C. Hepatology 2010; 52:833.

12.Cardoso AC, Moucari R, Figueiredo-Mendes C, Ripault $M P$, Giuily N, Castelnau C. Impact of peginterferon and ribavirin therapy on hepatocellular carcinoma: incidence and survival in hepatitis $C$ patients with advanced fibrosis. $J$ Hepatol 2010; 52:652.

13. Di Bisceglie AM, Ghalib RH, Hamzeh FM, Rustgi VK.
Early virologic response after peginterferon alpha-2a plus ribavirin or peginterferon alpha-2b plus ribavirin treatment in patients with chronic hepatitis C. J Viral Hepat 2007; 14:721. 14. Recommendations for testing, managing, and treating hepatitis C. Accessed April 24, 2014.

15. Tilg H. New insights into the mechanisms of interferon alfa: an immunoregulatory and anti-inflammatory cytokine. Gastroenterology 1997; 112:1017.

43.Feld JJ, Hoofnagle JH. Mechanism of action of interferon and ribavirin in treatment of hepatitis C. Nature 2005; 436:967

16. Laguno M, Cifuentes C, Murillas J, Veloso S, Larrousse $M$, Payeras $A$, et al. Randomized trial comparing pegylated interferon alpha-2b versus pegylated interferon alpha-2a, both plus ribavirin, to treat chronic hepatitis $C$ in human immunodeficiency virus patients. Hepatology 2009; 49:22.

17. Rumi MG, Aghemo A, Prati GM, D'Ambrosio R, Donato $M F$, Soffredini $R$, , et al. Randomized study of peginterferonalpha2a plus ribavirin vs peginterferon-alpha2b plus ribavirin in chronic hepatitis C. Gastroenterology 2010; 138:108.

18.Ascione A, De Luca M, Tartaglione MT, Lampasi F, Di Costanzo GG, Lanza AG, et al. Peginterferon alfa-2a plus ribavirin is more effective than peginterferon alfa- $2 b$ plus ribavirin for treating chronic hepatitis $C$ virus infection. Gastroenterology 2010; 138:116.

19.Ning Q, Brown D, Parodo J, Cattral M, Gorczynski $R$, Cole E, et al. Ribavirin inhibits viral-induced macrophage production of TNF, IL-1, the procoagulant fgl2 prothrombinase and preserves Thl cytokine production but inhibits Th2 cytokine response. J Immunol 1998; 160:3487

20.Crotty S, Maag D, Arnold JJ, Zhong W, Lau JY, Hong $Z$, Andino $R$, Cameron CE. The broad-spectrum antiviral ribonucleoside ribavirin is an RNA virus mutagen. Nat Med 2000; 6:1375

21.Lee JS, Kim SG, Kim HK, Lee TH, Jeong YI, Lee CM, et al. Silibinin polarizes Thl/Th2 immune responses through the inhibition of immunostimulatory function of dendritic cells. $J$ Cell Physiol. 2007;210:385-397. [PubMed]

22.Manna SK, Mukhopadhyay A, Van NT, Aggarwal BB. Silymarin suppresses TNF-induced activation of NF-kappa B, c-Jun N-terminal kinase, and apoptosis. J Immunol. 1999; 163:6800-6809.

23.Par Al, Roth E, MisetaA, Hegedüs G, Pár G, Hunyady $B$, Vincze A. Effects of supplementation with the antioxidant flavonoid, silymarin, in chronic hepatitis $C$ patients treated with peg-interferon + ribavirin. A Orv Hetil. 2009 Jan $l l ; 150(2): 73-9$

24. Legalon (MILK THISTLE): Uses, Side Effects, Interactions. www. webmd.com/.../ingredientmono138-Legalon\%20...(15/5/2014). 